\title{
Direct and highly productive conversion of cyanobacteria Arthrospira platensis to ethanol with $\mathrm{CaCl}_{2}$ addition
}

\author{
Shimpei Aikawa ${ }^{1,2,8}$, Kentaro Inokuma', Satoshi Wakai ${ }^{1}$, Kengo Sasaki ${ }^{1}$, Chiaki Ogino ${ }^{3}$, Jo-Shu Chang 4,5,6,
} Tomohisa Hasunuma ${ }^{1,2}$ and Akihiko Kondo ${ }^{1,7^{*}}$

\begin{abstract}
Background: The cyanobacterium Arthrospira platensis shows promise as a carbohydrate feedstock for biofuel production. The glycogen accumulated in A. platensis can be extracted by lysozyme-degrading the peptidoglycan layer of the bacterial cell walls. The extracted glycogen can be converted to ethanol through hydrolysis by amylolytic enzymes and fermentation by the yeast Saccharomyces cerevisiae. Thus, in the presence of lysozyme, a recombinant yeast expressing a-amylase and glucoamylase can convert A. platensis directly to ethanol, which would simplify the procedure for ethanol production. However, the ethanol titer and productivity in this process are lower than in ethanol production from cyanobacteria and green algae in previous reports.
\end{abstract}

Results: To increase the ethanol titer, a high concentration of A. platensis biomass was employed as the carbon source for the ethanol production using a recombinant amylase-expressing yeast. The addition of lysozyme to the fermentation medium increased the ethanol titer, but not the ethanol productivity. The addition of $\mathrm{CaCl}_{2}$ increased both the ethanol titer and productivity by causing the delamination of polysaccharide layer on the cell surface of $A$. platensis. In the presence of lysozyme and $\mathrm{CaCl}_{2}$, ethanol titer, yield, and productivity improved to $48 \mathrm{~g} \mathrm{~L}^{-1}, 93 \%$ of theoretical yield, and $1.0 \mathrm{~g} \mathrm{~L}^{-1} \mathrm{~h}^{-1}$ from A. platensis, corresponding to $90 \mathrm{~g} \mathrm{~L}^{-1}$ of glycogen.

Conclusions: We developed an ethanol conversion process using a recombinant amylase-expressing yeast from $A$. platensis with a high titer, yield, and productivity by adding both lysozyme and $\mathrm{CaCl}_{2}$. The direct and highly productive conversion process from A. platensis via yeast fermentation could be applied to multiple industrial bulk chemicals.

Keywords: Ethanol conversion, Glycogen extraction, Cyanobacteria, Amylase-displaying yeast, Polysaccharide layer, Organic nutrient

\section{Background}

Cyanobacteria and green algae show promise as a carbohydrate feedstock for biorefinery and for the production of fuels and chemicals from biomass [1,2]. They have a high carbohydrate content (> 50\% of dry-cell weight) in nutrient-depleted conditions [3-5]. Cyanobacteria and microalgae, which primarily grow in aquatic environments, have the benefit of year-round cultivation using non-arable lands [6]. Some species, such as the

\footnotetext{
*Correspondence: akondo@kobe-u.ac.jp

${ }^{1}$ Graduate School of Science, Technology, and Innovation, Kobe University, 1-1 Rokkodai, Nada-ku, Kobe 657-8501, Japan

Full list of author information is available at the end of the article
}

cyanobacterium Arthrospira platensis or the green alga Chlorella sp., can convert solar energy into biomass more efficiently than energy crops such as switchgrass or C3 crops [7]. As summarized in Table 1, ethanol production from cyanobacteria and green algae by microbial fermentation has been developed in previous works.

The carbohydrates in cyanobacteria and green algae are mainly glucose polymers (polyglucans) such as starch, glycogen, or cellulose $[5,8,9]$. The $S$. cerevisiae and Zymomonas mobilis commonly used for ethanol production cannot hydrolyze polyglucans. Therefore, acid or enzymatic hydrolysis is commonly employed to obtain fermentable sugars, such as glucose, from cyanobacteria 
Table 1 Ethanol production from cyanobacteria or green algae by microbial fermentation

\begin{tabular}{|c|c|c|c|c|c|c|}
\hline Species & Hydrolysis procedure & $\begin{array}{l}\text { Fermentation } \\
\text { type }\end{array}$ & $\begin{array}{l}\text { Ethanol } \\
\text { titer }\left(\mathrm{g} \mathrm{L}^{-1}\right)\end{array}$ & $\begin{array}{l}\text { Ethanol yield } \\
\left(\mathrm{g} \text {-ethanol }(\mathrm{g}-\mathrm{DCW})^{-1}\right)\end{array}$ & $\begin{array}{l}\text { Ethanol } \\
\text { productivity } \\
\left(\mathrm{g} \mathrm{L}^{-1} \mathrm{~h}^{-1}\right)\end{array}$ & References \\
\hline \multicolumn{7}{|l|}{ Green algae } \\
\hline Chlamydomonas reinhardtii & Acid & SHF & 15 & 0.29 & 0.61 & [13] \\
\hline Chlorella sp. & Acid & SHF & 23 & 0.29 & 0.60 & [14] \\
\hline Chlorella vulgaris & Acid & SHF & 12 & 0.23 & 1.2 & [5] \\
\hline Scenedesmus obliquus & Acid & SHF & 12 & 0.02 & 1.1 & [11] \\
\hline Scenedesmus acutus & Acid & SHF & 23 & 0.20 & 1.5 & [15] \\
\hline C. reinhardtii & Enzymatic & SHF & 12 & 0.24 & 0.3 & [10] \\
\hline C. vulgaris & Enzymatic & SSF & 4.3 & 0.21 & 0.16 & [5] \\
\hline \multicolumn{7}{|l|}{ Cyanobacteria } \\
\hline Synechococcus sp. & Enzymatic & SHF & 30 & 0.27 & 0.83 & {$[12]$} \\
\hline A. platensis & Enzymatic & SSF & 6.0 & 0.32 & 0.60 & [8] \\
\hline A. platensis & Enzymatic & CBP & 6.5 & 0.35 & 0.14 & {$[8]$} \\
\hline A. platensis & Enzymatic & CBP & 48 & 0.32 & 1.0 & This study \\
\hline
\end{tabular}

SHF separate hydrolysis and fermentation, SSF simultaneous saccharification and fermentation, CBP consolidated bioprocess, DCW dry-cell weight

and green algae $[5,10-15, \mathrm{~A} 1]$. We have developed an ethanol production from the cyanobacterium A. platensis using a recombinant amylase-expressing yeast [8]. A. platensis accumulates glycogen (a glucose polymer linked linearly by $\alpha-1,4$ glycosidic bonds with branches at the $\alpha-1,6$ positions) intracellularly at $60-70 \%$ of dry-cell weight in nitrogen-depleted conditions [3]. Lysozyme, by degrading the peptidoglycan layer of bacterial cell walls, liberates the glycogen accumulated in A. platensis [8]. Amylolytic enzymes, including $\alpha$-amylase and glucoamylase, can hydrolyze glycogen to glucose, which is fermentable by $S$. cerevisiae. Thus, in the presence of lysozyme, a recombinant $S$. cerevisiae strain expressing $\alpha$-amylase and glucoamylase can produce ethanol directly from $A$. platensis with a high ethanol yield [0.35 g-ethanol (g drycell weight $\left.)^{-1}\right]$ [8]. However, ethanol titer $\left(6.5 \mathrm{~g} \mathrm{~L}^{-1}\right)$ and ethanol productivity $\left(0.14 \mathrm{~g} \mathrm{~L}^{-1} \mathrm{~h}^{-1}\right)$ are much lower than those found in the previous research [8]. Achieving higher ethanol titers inevitably requires higher substrate loading during fermentation. Since ethanol productivity from the extracted glycogen of $A$. platensis is higher than that from non-pretreated $A$. platensis [8], we hypothesized that the rate of glycogen extraction from $A$. platensis limits ethanol productivity.

In the present study, to increase the ethanol titer, ethanol production was performed using a high concentration of $A$. platensis biomass. The polysaccharide layer on the cell surface of $A$. platensis includes lipopolysaccharide composing an outer membrane and extracellular polysaccharides [16], which form a barrier to glycogen extraction. To rapidly extract intercellular glycogen, we tried to enhance the permeability of the polysaccharide layer of A. platensis. In general, a high concentration of divalent cations such as $\mathrm{Ca}^{2+}$ or $\mathrm{Mg}^{2+}$ can increase the permeability of the polysaccharide layer of some bacteria, such as Escherichia coli or Salmonella typhimurium [17-19]. Pretreatment with $50 \mathrm{mM} \mathrm{CaCl}$, for instance, makes E. coli susceptible to DNA transfection and transformation [17]. Pretreatment of S. typhimurium cells with $100 \mathrm{mM} \mathrm{MgCl}{ }_{2}$ enhances the release of periplasmic $\beta$-lactamase [18]. However, the effect of metal salts on the permeability of the polysaccharide layer of cyanobacteria has never been reported. We therefore examined the effect of metal salts on glycogen extraction from A. platensis. Conclusively, we succeeded in developing a direct and highly productive process for conversion of $A$. platensis to ethanol using a recombinant amylase-expressing yeast strain.

\section{Results and discussion}

Effects of lysozyme on ethanol production from a high concentration of $A$. platensis biomass

The addition of lysozyme, which degrades the peptidoglycan layer, to a fermentation medium enhances ethanol production from the dilute concentration of $A$. platensis biomass (20 g dry-cell weight $\left.\mathrm{L}^{-1}\right)$ [8]. We examined the effect of $1 \mathrm{~g} \mathrm{~L}^{-1}$ (6.7 $\mathrm{mg}$ (g dry-cell weight $)^{-1}$ ) of lysozyme on ethanol production from a high concentration of $A$. platensis (150 g dry-cell weight $\mathrm{L}^{-1}$ ) using $S$. cerevisiae strain BY4741 AASS/GASS. The Streptococcus bovis $\alpha$-amylase gene and Rhizopus oryzae glucoamylase gene are expressed by this strain. $\mathrm{pH}$ was maintained at 5.2-5.4 during yeast fermentation, without interference. Therefore, we did not control $\mathrm{pH}$ for yeast fermentation in this 
study. The ethanol production in the absence or presence of lysozyme at 38 and $40{ }^{\circ} \mathrm{C}$ is shown in Fig. 1a. In the absence of lysozyme, ethanol titer and ethanol yield were $26 \mathrm{~g} \mathrm{~L}^{-1}$ and $0.17 \mathrm{~g}$-ethanol ( $\mathrm{g}$ dry-cell weight) ${ }^{-1}$ at $38^{\circ} \mathrm{C}$, and $22 \mathrm{~g} \mathrm{~L}^{-1}$ and $0.15 \mathrm{~g}$-ethanol (g dry-cell weight) ${ }^{-1}$ at $40{ }^{\circ} \mathrm{C}$. The addition of lysozyme increased ethanol titer and ethanol yield to $40 \mathrm{~g} \mathrm{~L}^{-1}$ and $0.27 \mathrm{~g}$-ethanol (g drycell weight) $)^{-1}$ at both 38 and $40{ }^{\circ} \mathrm{C}$. These results indicate that lysozyme addition effectively enhances ethanol production from a higher concentration of A. platensis biomass. Concerning the effect of fermentation temperature on ethanol productivity in the presence of lysozyme, the ethanol productivity at $40{ }^{\circ} \mathrm{C}\left(0.33 \mathrm{~g} \mathrm{~L}^{-1} \mathrm{~h}^{-1}\right)$ was superior to that at $38{ }^{\circ} \mathrm{C}\left(0.25 \mathrm{~g} \mathrm{~L}^{-1} \mathrm{~h}^{-1}\right)$, as shown in Fig. 1a. Intracellular glycogen was released to the cell exterior, following lysis of $A$. platensis cells during fermentation. The total glycogen concentration of intracellular and extracted glycogens in the fermentation medium in the presence of lysozyme at 38 and $40{ }^{\circ} \mathrm{C}$ is shown in Fig. $1 \mathrm{~b}$. As shown in Fig. 1b, there was a tendency that the glycogen consumption at $40{ }^{\circ} \mathrm{C}$ was faster than that at $38{ }^{\circ} \mathrm{C}$. This result agrees with the difference observed in the ethanol productivity in the presence of lysozyme between 38 and $40^{\circ} \mathrm{C}$ shown in Fig. 1a. However, the ethanol productivity in the presence of lysozyme at $40^{\circ} \mathrm{C}\left(0.33 \mathrm{~g} \mathrm{~L}^{-1} \mathrm{~h}^{-1}\right)$ was still lower compared to that in the previous studies shown in Table $1\left(0.60-1.5 \mathrm{~g} \mathrm{~L}^{-1} \mathrm{~h}^{-1}\right)$. The degradation of the peptidoglycan layer by lysozyme would not sufficiently enhance ethanol productivity from $A$. platensis. Since the ethanol productivity from the extracted glycogen of A. platensis $\left(0.60 \mathrm{~g} \mathrm{~L}^{-1} \mathrm{~h}^{-1}\right)$ was faster than that from non-pretreated A. platensis cells $\left(0.14 \mathrm{~g} \mathrm{~L}^{-1} \mathrm{~h}^{-1}\right)$ as shown in Table 1 [8], we hypothesized that accelerating glycogen extraction from A. platensis during fermentation increases ethanol productivity.

\section{Effects of metal salts on polysaccharides on the cell surface of $A$. platensis}

We observed the effects of metal salts on the polysaccharide layer surrounding the $A$. platensis cells by staining with toluidine blue. Under control condition, the cell surfaces were uniformly stained purple with toluidine blue as shown in Fig. 2. The polysaccharide layer properly surrounded the A. platensis cells. In contrast, the cells treated with $100 \mathrm{mM} \mathrm{CaCl}_{2}$ were non-uniformly stained and aggregates, which are likely the delaminated polysaccharides, were observed around the cell surface. This phenomenon was not observed under the other tested conditions $\left(10 \mathrm{mM} \mathrm{CaCl}_{2}, 10\right.$ and $100 \mathrm{mM} \mathrm{MgCl}_{2}$, and 10 and $100 \mathrm{mM} \mathrm{NaCl}$ ). Under these conditions, the cell surfaces were uniformly stained and aggregates were not observed as shown in Fig. 2. Multivalent metal cations, such as $\mathrm{Ca}^{2+}$, coagulate extracellular polysaccharides of a cyanobacterium Microcystis aeruginosa to form a gel [20]. Polysaccharide coagulation by a high concentration of $\mathrm{Ca}^{2+}$ would lead to delamination of the polysaccharides in $100 \mathrm{mM} \mathrm{CaCl}_{2}$. In contrast, $\mathrm{Mg}^{2+}$ and $\mathrm{Na}^{+}$did not induce the polysaccharide delamination, regardless of the concentration. The valence of $\mathrm{Na}^{+}$is insufficient for polysaccharide aggregation [20,21]. The different structural changes in the polysaccharides induced by $\mathrm{Ca}^{2+}$ and $\mathrm{Mg}^{2+}$ have been previously reported [22-24]. The difference may be caused by differences in the hydration properties of $\mathrm{Ca}^{2+}$ and $\mathrm{Mg}^{2+}$, such as the Pauling radius, coordination number, or hydration energy $[22,23]$. The cell surface polysaccharide in A. platensis has sulfate
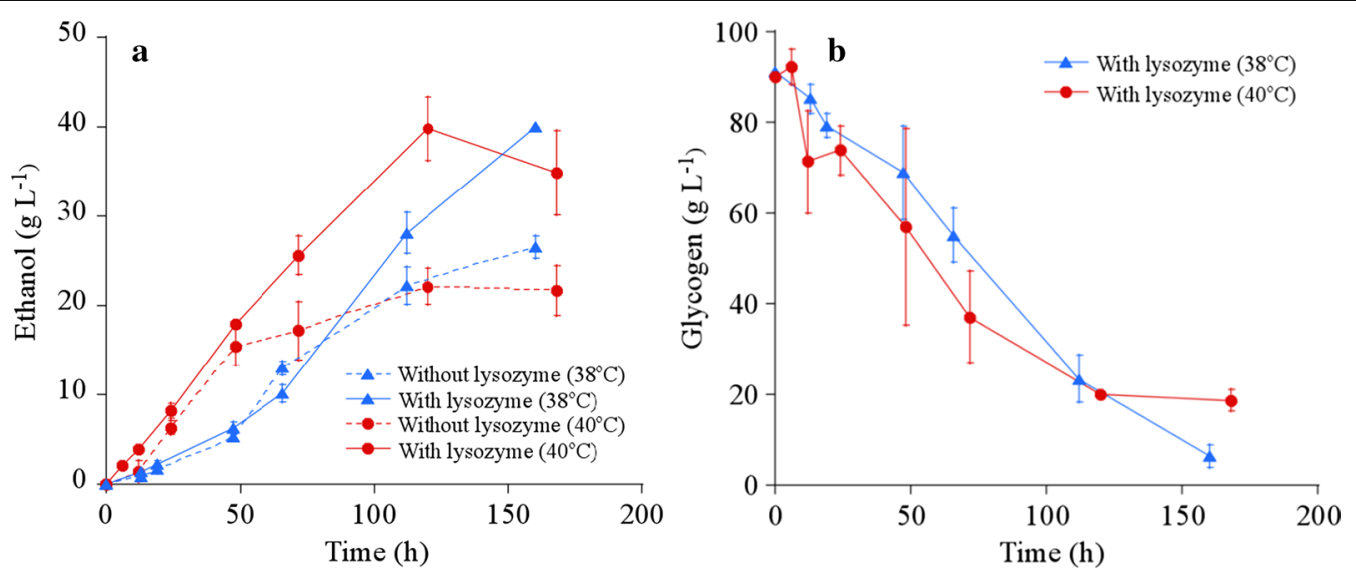

Fig. 1 Ethanol production from a high concentration of A. platensis biomass in the presence of lysozyme. a Ethanol production in the presence of $1 \mathrm{~g} \mathrm{~L}^{-1}$ lysozyme (solid line) and the absence of lysozyme (dotted line) at $38^{\circ} \mathrm{C}$ (blue triangle) and $40^{\circ} \mathrm{C}$ (red circle). $\mathbf{b}$ Glycogen consumption in the presence of $1 \mathrm{~g} \mathrm{~L}^{-1}$ of lysozyme at $38^{\circ} \mathrm{C}$ (blue triangle) and $40^{\circ} \mathrm{C}$ (red circle). Error bars indicate standard deviations (SD) of three replicated experiments. For some data points, error bars obtained by three replications are smaller than the symbols 

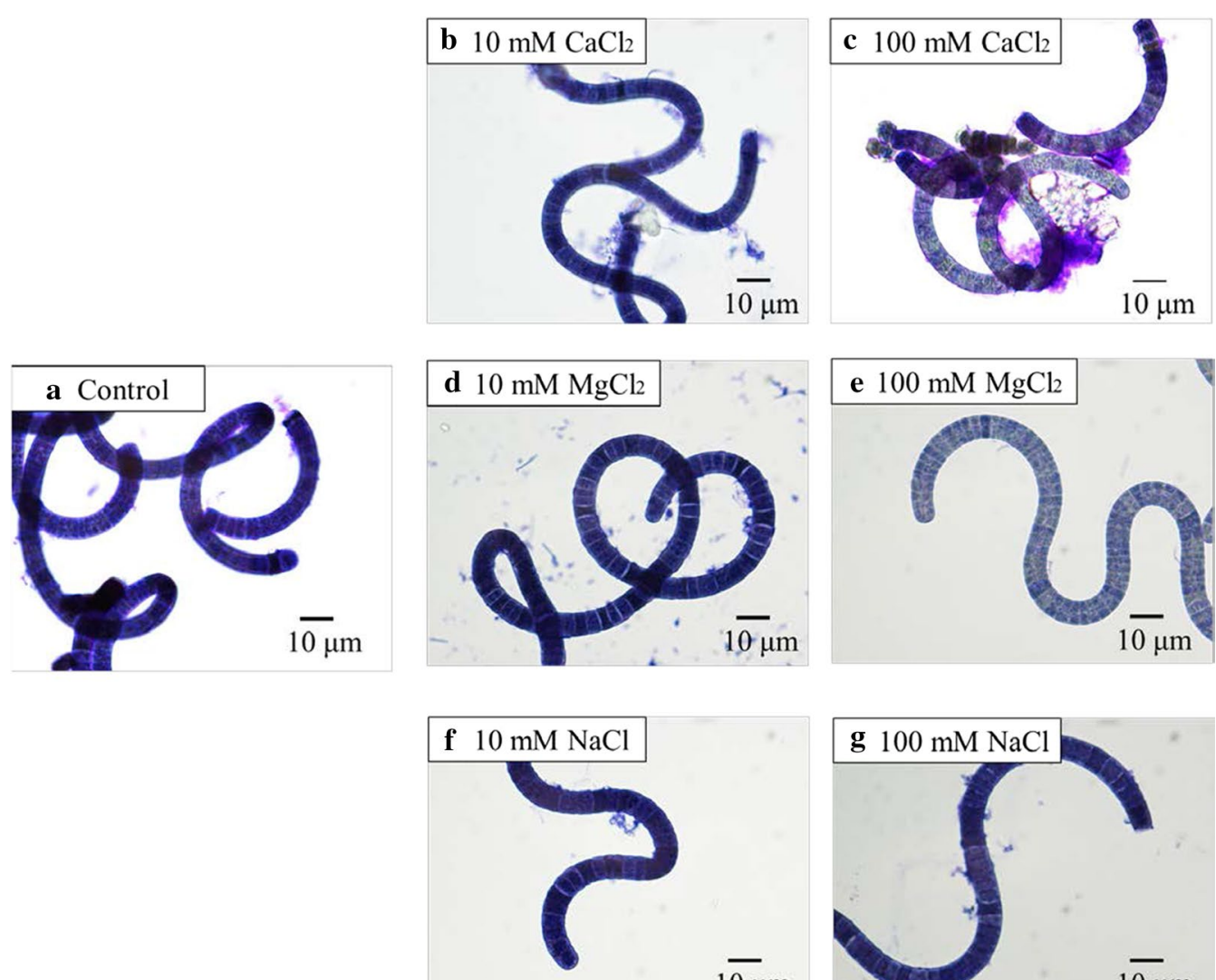

$\overline{10 \mu \mathrm{m}}$

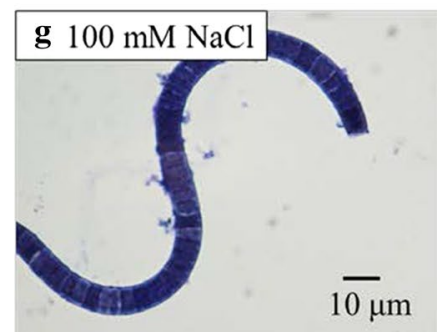

Fig. 2 Effects of metal salts on polysaccharides on the cell surface of A. platensis. a Control (no addition of metal salts); b $10 \mathrm{mM} \mathrm{CaCl} ; \mathbf{c} 100 \mathrm{mM}$ $\mathrm{CaCl}_{2} ; \mathbf{d} 10 \mathrm{mM} \mathrm{MgCl}_{2} ; \mathbf{e} 100 \mathrm{mM} \mathrm{MgCl} ; \mathbf{f} 10 \mathrm{mM} \mathrm{NaCl} ; \mathbf{g} 100 \mathrm{mM} \mathrm{NaCl}$

groups of unknown localization and carbohydrate groups of uronic acids, such as glucuronic acid and galacturonic acid $[25] . \mathrm{Ca}^{2+}$ would therefore preferentially bind to the sulfonate and carboxylate groups of the polysaccharides, as compared to $\mathrm{Mg}^{2+}$ [22]. Accordingly, the polysaccharide in A. platensis would be delaminated only at $100 \mathrm{mM}$ $\mathrm{CaCl}_{2}$, as shown in Fig. 2 .

\section{Effects of lysozyme and $\mathrm{CaCl}_{2}$ on glycogen extraction from A. platensis}

We investigated the effects of lysozyme $\left(1 \mathrm{~g} \mathrm{~L}^{-1}\right)$ or $\mathrm{CaCl}_{2}$ $(100 \mathrm{mM})$ on glycogen extraction from A. platensis, corresponding to $90 \mathrm{~g} \mathrm{~L}^{-1}$ of glycogen. This was carried out in $50-\mathrm{mL}$ polypropylene tubes under axial rotation of $30 \mathrm{rpm}$ at $40{ }^{\circ} \mathrm{C}$. Only a limited amount of intracellular glycogen was extracted from $A$. platensis in the absence of carbohydrate-hydrolyzing enzymes. Therefore, glycogen was extracted in the presence of $0.3 \mathrm{U} \mathrm{L}^{-1} \alpha$-amylase and $0.1 \mathrm{U} \mathrm{L}^{-1}$ glucoamylase. The glucose concentration in the supernatant with neither lysozyme nor $\mathrm{CaCl}_{2}$, either lysozyme or $\mathrm{CaCl}_{2}$, and both lysozyme and $\mathrm{CaCl}_{2}$ is shown in Fig. 3. The glucose concentration was $43 \mathrm{~g} \mathrm{~L}^{-1}$ without lysozyme or $\mathrm{CaCl}_{2}$ after $168 \mathrm{~h}$. Lysozyme addition to the cell slurry of $A$. platensis increased the glucose concentrations to $67 \mathrm{~g} \mathrm{~L}^{-1}$ after $168 \mathrm{~h}$. However, up to $48 \mathrm{~h}$, the glucose concentration in the presence of lysozyme was similar to that without lysozyme or $\mathrm{CaCl}_{2}$ (Fig. 3). For instance, at $24 \mathrm{~h}$, the glucose concentration was $9.4 \mathrm{~g} \mathrm{~L}^{-1}$ with lysozyme and $8.3 \mathrm{~g} \mathrm{~L}^{-1}$ without lysozyme or $\mathrm{CaCl}_{2}$. In contrast, the glucose concentration rapidly increased to $67 \mathrm{~g} \mathrm{~L}^{-1}$ with $\mathrm{CaCl}_{2}$ after $24 \mathrm{~h}$ (Fig. 3). Adding both lysozyme and $\mathrm{CaCl}_{2}$ further increased the glucose concentration to $83 \mathrm{~g} \mathrm{~L}^{-1}$ at $24 \mathrm{~h}$. A. platensis cells would be disrupted more rapidly and thoroughly due to polysaccharide delamination on the cell surface by $\mathrm{CaCl}_{2}$ and degradation of the peptidoglycan layer by lysozyme, which would result in acceleration of glycogen extraction, as illustrated in Additional file 1.

\section{Ethanol production from A. platensis in the presence of lysozyme and $\mathrm{CaCl}_{2}$}

We performed ethanol production from $A$. platensis by $S$. cerevisiae strain BY4741 AASS/GASS in the presence of both $1 \mathrm{~g} \mathrm{~L}^{-1}$ lysozyme and $100 \mathrm{mM} \mathrm{CaCl}_{2}$ (for 


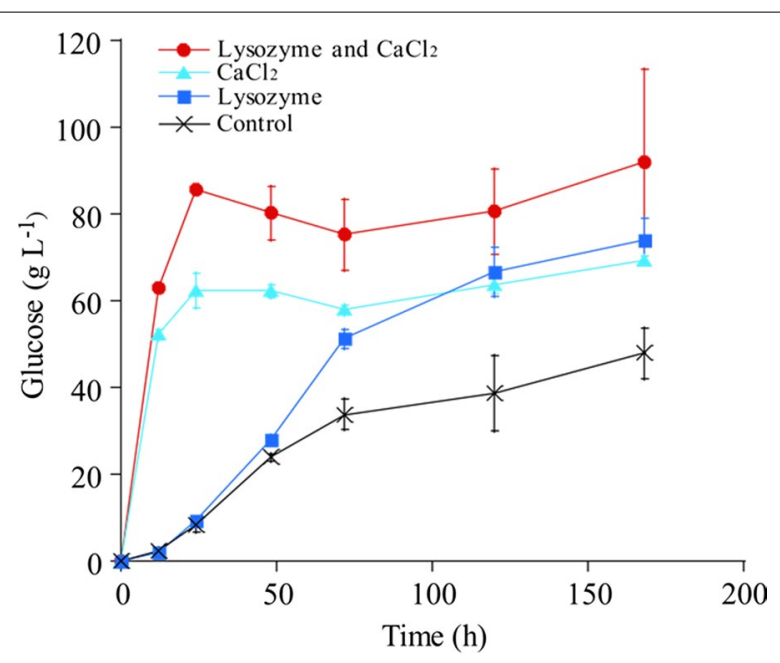

Fig. 3 Effects of lysozyme and $\mathrm{CaCl}_{2}$ on glycogen extraction from $\mathrm{A}$. platensis. Glucose concentrations in supernatant of the cell slurry of $A$. platensis in the presence of a-amylase and glucoamylase with neither lysozyme nor $\mathrm{CaCl}_{2}$ (black cross), lysozyme (blue square), $\mathrm{CaCl}_{2}$ (light blue triangle), and both lysozyme and $\mathrm{CaCl}_{2}$ (red circle) at $40^{\circ} \mathrm{C}$. Error bars indicate the SD of three replicated experiments. For some data points, error bars obtained by three replications are smaller than the symbols

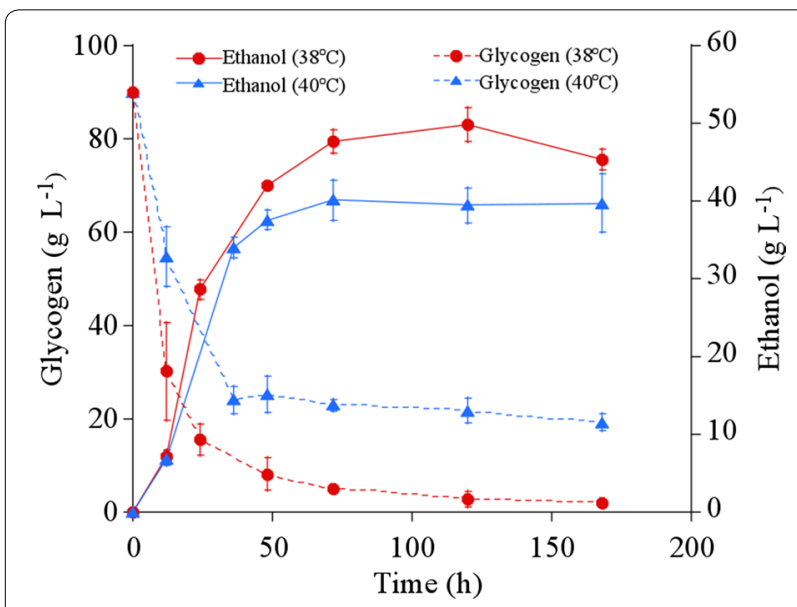

Fig. 4 Ethanol production from A. platensis with $\mathrm{CaCl}_{2}$ addition in the presence of lysozyme. Ethanol production (solid line) and glycogen consumption (dotted line); ethanol was produced at $38^{\circ} \mathrm{C}$ (blue triangle) and $40{ }^{\circ} \mathrm{C}$ (red circle). Error bars indicate SD of three replicated experiments. For some data points, error bars obtained by three replications are smaller than the symbols

enhancing glycogen extraction) at 38 and $40{ }^{\circ} \mathrm{C} . \mathrm{CaCl}_{2}$ addition to the fermentation medium increased ethanol productivity to $1.0 \mathrm{~g} \mathrm{~L}^{-1} \mathrm{~h}^{-1}$ at both 38 and $40^{\circ} \mathrm{C}$ (Fig. 4), although without addition the values were $0.25 \mathrm{~g} \mathrm{~L}^{-1} \mathrm{~h}^{-1}$ at $38{ }^{\circ} \mathrm{C}$ or $0.33 \mathrm{~g} \mathrm{~L}^{-1} \mathrm{~h}^{-1}$ at $40{ }^{\circ} \mathrm{C}$ (Fig. 1a). Here, $A$. platensis biomass was employed without physical pretreatment and enzymatic hydrolysis of carbohydrate. Nevertheless, the ethanol productivity was comparable to that from hydrolysates of cyanobacteria and green algae (0.60-1.5 $\mathrm{g} \mathrm{L}^{-1} \mathrm{~h}^{-1}$; Table 1$)$. These results support our hypothesis that accelerating glycogen extraction from A. platensis during fermentation can improve ethanol productivity. However, it is expected that ethanol productivity should be increased to $>1.5 \mathrm{~g} \mathrm{~L}^{-1} \mathrm{~h}^{-1}$, because the glucose concentration obtained from $A$. platensis was $83 \mathrm{~g} \mathrm{~L}^{-1}$ after $24 \mathrm{~h}$ (Fig. 3). The activity of amylases expressing on the yeast cell surface may limit ethanol productivity. To obtain higher ethanol productivity, higher amylase activity would be required. As shown in Fig. $4, \mathrm{CaCl}_{2}$ addition increased the ethanol titer and yield at $38{ }^{\circ} \mathrm{C}$ to $48 \mathrm{~g} \mathrm{~L}^{-1}$ and 0.32 g-ethanol (g dry-cell weight $)^{-1}$. In contrast, the ethanol titer and the ethanol yield at $40{ }^{\circ} \mathrm{C}$ were $40 \mathrm{~g} \mathrm{~L}^{-1}$ and $0.27 \mathrm{~g}$-ethanol (g drycell weight $)^{-1}$, which were similar to those without $\mathrm{CaCl}_{2}$ at $40{ }^{\circ} \mathrm{C}$ (Fig. 1a). The glycogen consumption at $40{ }^{\circ} \mathrm{C}$ was slower than at $38{ }^{\circ} \mathrm{C}$, and $20 \mathrm{~g} \mathrm{~L}^{-1}$ of glycogen was left over at $40{ }^{\circ} \mathrm{C}$ (Fig. 4). Glucose was barely detectable in the supernatant at $40{ }^{\circ} \mathrm{C}$ during fermentation (data not shown). These results indicate that the activities of amylases displayed on the yeast cell surface were decreased at $40{ }^{\circ} \mathrm{C}$. Retaining amylase activity would be vital to further improve the ethanol productivity in high-temperature conditions $\left(>40{ }^{\circ} \mathrm{C}\right)$. Finally, the addition of both $\mathrm{CaCl}_{2}$ and lysozyme improved the ethanol titer to $48 \mathrm{~g} \mathrm{~L}^{-1}$ at $38{ }^{\circ} \mathrm{C}$. The ethanol titer obtained was larger than those found in the previous studies shown in Table 1. The energy required for ethanol distillation or membrane recovery and dehydration of ethanol is significantly higher when the ethanol titer is less than $40 \mathrm{~g} \mathrm{~L}^{-1}$ [2628]. Therefore, higher ethanol titers reduce the energy requirement of ethanol distillation.

\section{Ethanol production from A. platensis without organic nutrients by $\mathrm{CaCl}_{2}$ addition}

Organic nutrients, such as yeast extract, peptone, or corn steep liquor, are generally necessary in a fermentation medium to support yeast fermentation [29]. The cost of organic nutrients is expensive for ethanol production. The lysates of the cyanobacteria Synechococcus sp., or the green algae Scenedesmus acutus, have a similar beneficial effect as organic nutrients during yeast fermentation [12, 15]. A. platensis contains nutrients such as free amino acids, vitamins, and minerals [30], which are likely utilized as a replacement of the organic nutrients in a fermentation medium. We carried out ethanol production from non-pretreated A. platensis by $S$. cerevisiae strain BY4741 AASS/GASS without organic nutrients in the presence of $1 \mathrm{~g} \mathrm{~L}^{-1}$ lysozyme and $100 \mathrm{mM} \mathrm{CaCl}_{2}$ at $38{ }^{\circ} \mathrm{C}$, as shown in Fig. 5 . The ethanol titer $\left(48 \mathrm{~g} \mathrm{~L}^{-1}\right)$, 


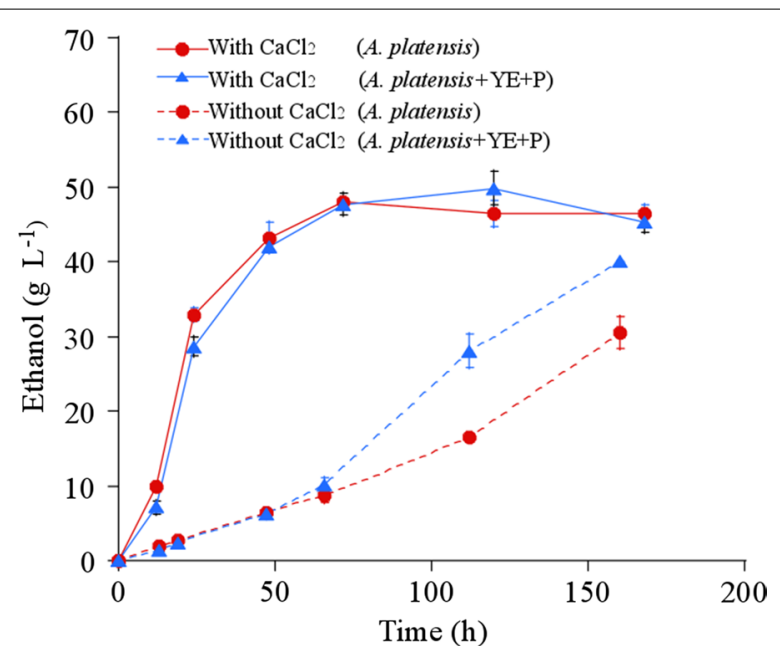

Fig. 5 Ethanol production from A. platensis without organic nutrients, in the absence or presence of $\mathrm{CaCl}_{2}$. Ethanol production with organic nutrients (blue triangle) or without organic nutrients (red circle) at $38^{\circ} \mathrm{C}$ in the presence of $\mathrm{CaCl}_{2}$ (solid line) and in the absence of $\mathrm{CaCl}_{2}$ (dotted line). YE and $\mathrm{P}$ mean yeast extract and bacto peptone, respectively. The data for ethanol production with organic nutrients and $\mathrm{CaCl}_{2}$ are the same as that in Fig. 4. The data for ethanol production with organic nutrients but without $\mathrm{CaCl}_{2}$ are same as that in Fig. 1a. Error bars indicate the SD of three replicated experiments. For some data points, error bars obtained by three replications are smaller than the symbols

the ethanol yield [0.32 g-ethanol ( $\mathrm{g}$ dry-cell weight $)^{-1}$ ], and the ethanol productivity $\left(1.0 \mathrm{~g} \mathrm{~L}^{-1} \mathrm{~d}^{-1}\right)$ were similar to those obtained with organic nutrient addition. In contrast, in the presence of lysozyme and absence of $\mathrm{CaCl}_{2}$, the ethanol titer and productivity decreased when organic nutrients were not added (Fig. 5). The intracellular compounds efficiently extracted from $A$. platensis by lysozyme and $\mathrm{CaCl}_{2}$ would be supplied as nutrients for the yeast fermentation. These results indicate that direct ethanol production from $A$. platensis can be performed without exogenous nutrients for yeast fermentation.

\section{Advantages of ethanol production using an amylase-expressing yeast from $A$. platensis}

The process of direct ethanol production from $A$. platensis used in this study has several advantages over conventional processes: (1) physical pretreatment and enzymes that can hydrolyze polyglucan are not required; (2) high titer, productivity, and yield of ethanol production; (3) $\mathrm{pH}$ neutralization prior to microbial fermentation is not required unlike processes that adopt chemical hydrolysis; (4) exogenous organic nutrients are not required during microbial fermentation. The entire procedure for ethanol production was simplified because the developed process combines polyglucan (glycogen) extraction, hydrolytic enzyme production, polyglucan hydrolysis, and yeast fermentation. The physical cell breakage for polyglucan extraction is commonly necessary for ethanol production with enzymatic hydrolysis from cyanobacteria and green algae [5, 12]. The addition of both $100 \mathrm{mM}$ $\mathrm{CaCl}_{2}$ and $1 \mathrm{~g} \mathrm{~L}^{-1}$ of lysozyme can efficiently and rapidly extract glycogen from $A$. platensis without energyconsuming physical pretreatment. Ethanol production by a recombinant amylase-expressing yeast can omit amylase addition. A. platensis biomass was employed without physical pretreatment and polyglucan hydrolysis enzymes; nevertheless, the ethanol productivity and the ethanol yield were similar, and the ethanol titer was higher compared with the previous studies in Table 1. For ethanol production with chemical hydrolysis, $\mathrm{H}_{2} \mathrm{SO}_{4}$ or $\mathrm{HCl}$ was necessary for the polyglucan hydrolysis, and $\mathrm{CaCO}_{3}$ or $\mathrm{NaOH}$ was necessary for $\mathrm{pH}$ neutralization of hydrolysate $[5,11,13,14]$. In contrast, the developed process did not require any chemicals for $\mathrm{pH}$ adjustment, which may contribute to a decrease in environmental load or energy consumption. Lysozyme addition is an issue in this process, which could be overcome by development of a recombinant lysozymeexpressing yeast. It is expected that this conversion process for $A$. platensis could be applied to the production of multiple industrial bulk chemicals, such as pyruvic acid or succinic acid, as well as ethanol [31].

For ethanol production, it is essential to reduce the costs related to the harvest and cultivation of feedstocks. The annual biomass production of cyanobacteria and green algae is $3-10$ times higher than that of agricultural crops such as corn grain [6], but the costs of biomass production are 30-50 times more expensive $[32,33]$. Cell harvesting of cyanobacteria and microalgae occupies $20-30 \%$ of the total cost of biomass production [32]. Although centrifugation can recover cyanobacterial and green-algal cells from the cultivation medium, centrifugation is too expensive for ethanol production. A. platensis cells, having a long spiral shape (20-100 $\mu \mathrm{m}$ length), can be harvested by the relatively cost-efficient and energy-efficient micro-screen harvesting method [34]. The cultivation of cyanobacteria and green algae for ethanol production is unlikely to be economically viable or provide a positive energy return without wastewater utilization [32]. A. platensis can be cultivated using various agro-industrial wastes and wastewater in the cultivation medium [35]. However, we have to adopt strategies to overcome the issues that inhibit cell growth due to contamination and decrease in light energy. The advantages of using $A$. platensis as feedstock would contribute to a reduction in the cost of bioethanol production. 


\section{Conclusions}

In the direct ethanol conversion process from A. platensis by a recombinant amylase-expressing yeast, the ethanol titer and productivity have been extremely low compared with the conventional process. We developed a direct ethanol conversion process from A. platensis with a high titer, yield, and productivity using both $\mathrm{CaCl}_{2}$ and lysozyme in the present study. The addition of lysozyme to degrade the peptidoglycan layer increased the ethanol titer. The removal of the polysaccharide layer on the cell surface by $\mathrm{CaCl}_{2}$ accelerated glycogen extraction from $A$. platensis, which markedly increased ethanol productivity. Our findings indicate that $A$. platensis is a valuable feedstock for ethanol production by microbial fermentation. To further improve the direct ethanol conversion process from $A$. platensis, a recombinant yeast that expresses lysozyme would be important. This direct conversion process of $A$. platensis by yeast fermentation could be further applied to the production of multiple industrial bulk chemicals, such as pyruvic acid or succinic acid.

\section{Methods}

\section{Microorganism and growth conditions}

A cyanobacterium A. platensis NIES-39 was obtained from the Global Environmental Forum (Tsukuba, Japan). A. platensis cells were pre-cultured in $500-\mathrm{mL}$ Erlenmeyer flasks containing $250 \mathrm{~mL}$ of modified SOT medium with $100 \mathrm{rpm}$ agitation under continuous illumination at $50-\mu \mathrm{mol}$ photons $\mathrm{m}^{-2} \mathrm{~s}^{-1}$ for 7 days, with air-conditioning to maintain a temperature of $30 \pm 2{ }^{\circ} \mathrm{C}$ in an NC350-HC plant chamber (Nippon Medical and Chemical Instruments, Osaka, Japan). The SOT medium consisted of $16.8 \mathrm{~g} \mathrm{~L}^{-1} \mathrm{NaHCO}_{3}, 0.5 \mathrm{~g} \mathrm{~L}^{-1}$ $\mathrm{K}_{2} \mathrm{HPO}_{4}, 2.5 \mathrm{~g} \mathrm{~L}^{-1} \mathrm{NaNO}_{3}, 1.0 \mathrm{~g} \mathrm{~L}^{-1} \mathrm{~K}_{2} \mathrm{SO}_{4}, 1.0 \mathrm{~g} \mathrm{~L}^{-1}$ $\mathrm{NaCl}, 0.2 \mathrm{~g} \mathrm{~L}^{-1} \mathrm{MgSO}_{4} \cdot 7 \mathrm{H}_{2} \mathrm{O}, 0.04 \mathrm{~g} \mathrm{~L}^{-1} \mathrm{CaCl}_{2} \cdot 2 \mathrm{H}_{2} \mathrm{O}$, $0.01 \mathrm{~g} \mathrm{~L}^{-1} \mathrm{FeSO}_{4} \cdot 7 \mathrm{H}_{2} \mathrm{O}, 0.08 \mathrm{~g} \mathrm{~L}^{-1} \mathrm{Na}_{2}$ EDTA, and $0.1 \%$ (v/v) A5 solution [30]. The A5 solution consisted of $2.86 \mathrm{~g} \mathrm{~L}^{-1} \mathrm{H}_{3} \mathrm{BO}_{3}, 2.5 \mathrm{~g} \mathrm{~L}^{-1} \mathrm{MnSO}_{4} \cdot 7 \mathrm{H}_{2} \mathrm{O}, 0.222 \mathrm{~g} \mathrm{~L}^{-1}$ $\mathrm{ZnSO}_{4} \cdot 7 \mathrm{H}_{2} \mathrm{O}, 0.079 \mathrm{~g} \mathrm{~L}^{-1} \mathrm{CuSO}_{4} \cdot 5 \mathrm{H}_{2} \mathrm{O}$, and $0.021 \mathrm{~g} \mathrm{~L}^{-1}$ $\mathrm{Na}_{2} \mathrm{MoO}_{4} \cdot 2 \mathrm{H}_{2} \mathrm{O}$. Pre-cultivated cells were inoculated at 0.03 (g dry-cell weight) $\mathrm{L}^{-1}$ and grown in 2-L flattened flasks containing $1.4 \mathrm{~L}$ SOT medium with $3 \mathrm{mM}$ nitrate under continuous illumination at $500-\mu \mathrm{mol}$ photons $\mathrm{m}^{-2} \mathrm{~s}^{-1}$ using white fluorescent bulbs (Life Look HGX and NHG; NEC, Tokyo, Japan) at $29 \pm 1{ }^{\circ} \mathrm{C}$ with air bubbling at $350 \mathrm{~mL} \mathrm{~min}^{-1}$ for 3.5 days. The light intensity in the center of the medium was measured using an LI250A light meter (LI-COR, Lincoln, NE) equipped with an LI-190SA quantum sensor (LI-COR).

Saccharomyces cerevisiae strain BY4741 AASS/GASS, which expressed the $\alpha$-amylase gene from Streptococcus bovis and glucoamylase gene from Rhizopus oryzae [36], was grown aerobically in $500 \mathrm{~mL}$ YPD medium $\left(10 \mathrm{~g} \mathrm{~L}^{-1}\right.$ yeast extract, $20 \mathrm{~g} \mathrm{~L}^{-1}$ peptone, and $20 \mathrm{~g} \mathrm{~L}^{-1}$ glucose) at $30{ }^{\circ} \mathrm{C}$ with agitation at $150 \mathrm{rpm}$ for 2 days prior to fermentation.

\section{Observations of polysaccharides on the cell surface of $A$. platensis}

Arthrospira platensis cells cultivated for 7 days in SOT medium with $30 \mathrm{mM} \mathrm{NaNO}$ were collected with centrifugation $\left(6300 \times g\right.$ for $2 \mathrm{~min}$ at $\left.25^{\circ} \mathrm{C}\right)$, and then washed once with distilled water. The A. platensis cells were transferred at 0.7 (g dry-cell weight) $\mathrm{L}^{-1}$ to $10 \mathrm{~mL}$ of distilled water without additives, and $10 \mathrm{mM} \mathrm{CaCl}$, $100 \mathrm{mM} \mathrm{CaCl}, 10 \mathrm{mM} \mathrm{MgCl}, 100 \mathrm{mM} \mathrm{MgCl}, 10 \mathrm{mM}$ $\mathrm{NaCl}$, or $100 \mathrm{mM} \mathrm{NaCl}$ were added, each to one of 6-well plates. The mixtures were then rotated at $100 \mathrm{rpm}$ in an incubator HB-80 (TAITEC, Tokyo, Japan) for $30 \mathrm{~min}$ at $40{ }^{\circ} \mathrm{C}$. The lipopolysaccharide of $A$. platensis for each condition was stained by $0.05 \%(\mathrm{w} / \mathrm{v})$ toluidine blue (Nacalai Tesque, Kyoto, Japan) [37]. The polysaccharides on the cell surface of $A$. platensis were observed with a light microscope Eclipse TE 300 (Nikon, Tokyo, Japan), and images were digitized using a digital camera DS-Ri1 (Nikon).

\section{Glycogen extraction and ethanol fermentation from $A$. platensis}

Arthrospira platensis cells, cultivated for 3.5 days in SOT medium with $3 \mathrm{mM}$ nitrate, were collected with a nylon net filter $(30 \mathrm{~cm} \times 40 \mathrm{~cm}, 20-\mu \mathrm{m}$ pore size; Millipore, Billerica, MA), and then washed once with distilled water while still on the filter. To achieve high-titer ethanol production, a high-biomass concentration $\left(1.5 \mathrm{~kg}\right.$ wet-cell weight $\left.\mathrm{L}^{-1}\right)$ of A. platensis was used as the carbon source for yeast fermentation. The biomass volume was reduced by removing $40 \%(\mathrm{w} / \mathrm{w})$ of the raw biomass water content with cellulose absorptive sponges $(15 \mathrm{~cm} \times 9 \mathrm{~cm} \times 3 \mathrm{~cm}$, Toray Fine Chemicals, Chiba, Japan) and dehydrated by pressing at $500 \mathrm{~g} \times 100 \mathrm{~cm}^{-2}$. High-yield ethanol production from high-solid lignocellulosic biomass was performed in a drum-type rotatory fermenter to achieve sufficient mixing of the high-viscosity biomass [38]. Due to its simplicity and high potential for large-scale fermentation [39], a drum-type rotary fermenter (Thermo Block Rotator SN06BN; Nissin, Tokyo, Japan), which axially rotating 50-mL polypropylene tubes (Corning Inc., NY) at $30 \mathrm{rpm}$, was used for ethanol production from $A$. platensis biomass in the present study. The vessel was sealed with a silicon plug, into which a hole was bored using a disposable needle $(\phi=0.6 \mathrm{~mm})$ (Terumo Corp., Tokyo, Japan). Yeast cells were collected by centrifugation at $3000 \times g$ for $3 \mathrm{~min}$ at $25^{\circ} \mathrm{C}$, washed twice with distilled water, and inoculated with 50 (g wet-cell weight) $\mathrm{L}^{-1}$ into YP medium $\left(10 \mathrm{~g} \mathrm{~L}^{-1}\right.$ yeast extract and $20 \mathrm{~g} \mathrm{~L}^{-1}$ peptone) or distilled water 
containing A. platensis cells corresponding to $90 \mathrm{~g} \mathrm{~L}^{-1}$ glycogen. For the extraction of intracellular glycogen from $A$. platensis, $1 \mathrm{~g} \mathrm{~L}^{-1}$ lysozyme and $100 \mathrm{mM} \mathrm{CaCl}$ were added to the fermentation medium. Ethanol production with the S. cerevisiae strain BY4741 can be performed at $38-40{ }^{\circ} \mathrm{C}$ [40]. High-temperature fermentation offers advantages such as reduced contamination risks and cooling costs, and is therefore suitable for tropical countries [41]. Therefore, we produced ethanol from A. platensis at 38 and $40^{\circ} \mathrm{C}$ using the S. cerevisiae strain BY4741 AASS/GASS.

\section{Analytical methods}

The ethanol concentrations were analyzed using a GC2010 Plus gas chromatograph (Shimadzu, Kyoto, Japan) equipped with a GC-FID flame ionization detector (Shimadzu) and a DB-FFAP column $(60 \mathrm{~m} \times 0.250 \mathrm{~mm}$ i.d., $0.5 \mu \mathrm{m}$ film thickness; Agilent, Palo Alto, CA) with helium as the carrier gas. The column temperature was held at $40{ }^{\circ} \mathrm{C}$ for $1 \mathrm{~min}$ before being raised to $170{ }^{\circ} \mathrm{C}$ with a linear gradient of $10{ }^{\circ} \mathrm{C} \mathrm{min}{ }^{-1}$. The injector and detector temperatures were maintained at $230{ }^{\circ} \mathrm{C}$. The injection volume was $1 \mu \mathrm{L}$ and the split ratio was adjusted to 1:50.

The glycogen content of $A$. platensis cells was determined by HPLC (Shimadzu, Kyoto, Japan) using a sizeexclusion HPLC column (OHpak SB-806M HQ; Shodex, Tokyo, Japan) and a reflective index detector (RID-10A; Shimadzu, Kyoto, Japan), as previously described [42]. The concentration of extracted glycogen from A. platensis was calculated from the glucose concentration. The glucose concentration was determined using a highperformance liquid chromatograph (HPLC) (LC20A; Shimadzu) with an ion-exchange HPLC column (Unison UK-Amino UKA06; Imtakt, Kyoto, Japan) and an evaporative light scattering detector (ELSD-LTII; Shimadzu). Experimental data are shown as the triplicate sample means and error bars indicate the standard deviation.

The $\alpha$-amylase and glucoamylase activities were measured using an $\alpha$-amylase assay kit and a saccharifying ability assay kit (Kikkoman Corp., Chiba, Japan), respectively; 2-chloro-4-nitrophenyl $6^{5}$-azide- $6^{5}$-deoxy- $\beta$-maltopentaoside and 4-nitrophenyl$\beta$-D-maltoside were used as the substrates according to the manufacture's instruction.

\section{Additional file}

Additional file 1. Schematic diagram of glycogen extraction from $A$. platensis in the presence of lysozyme and $\mathrm{CaCl}_{2}$.

\section{Abbreviations}

CBP: consolidated bioprocess; HPLC: high-performance liquid chromatograph; SHF: separate hydrolysis and fermentation; SSF: simultaneous saccharification and fermentation.

\section{Authors' contributions}

SA performed the experiments, designed the study, and wrote the manuscript; Kl constructed the recombinant amylase-expressing yeasts; SW, KS, and CO mentioned important suggestion; JSC, TH, and AK coordinated the study. All authors read and approved the final manuscript.

\section{Author details}

${ }^{1}$ Graduate School of Science, Technology, and Innovation, Kobe University, 1-1 Rokkodai, Nada-ku, Kobe 657-8501, Japan. ${ }^{2}$ Core Research for Evolutional Science and Technology, Japan Science and Technology Agency, 3-5 Sanbancho, Chiyoda-ku, Tokyo 102-0075, Japan. ${ }^{3}$ Graduate School of Engineering, Kobe University, 1-1 Rokkodai, Nada-ku, Kobe 657-8501, Japan. ${ }^{4}$ Department of Chemical Engineering, National Cheng Kung University, Tainan 701, Taiwan. ${ }^{5}$ Research Center for Energy Technology and Strategy, National Cheng Kung University, Tainan 701, Taiwan. ${ }^{6}$ Center for Bioscience and Biotechnology, National Cheng Kung University, Tainan 701, Taiwan. ${ }^{7}$ Biomass Engineering Program, RIKEN, 1-7-22 Suehiro, Tsurumi-ku, Yokohama 230-0045, Japan. ${ }^{8}$ Present Address: Biological Resources and Post-Harvest Division, Japan International Research Center for Agricultural Sciences (JRCAS), 1-1 Ohwashi, Tsukuba, Ibaraki 305-8686, Japan.

\section{Acknowledgements}

The authors thank Ms. Chikako Aoki and Ms. Mika Kakuda for their technical assistance. We would like to thank Editage (http://www.editage.jp) for English language editing.

\section{Competing interests}

The authors declare that they have no competing interests.

\section{Availability of data and materials}

Not applicable.

\section{Consent for publication \\ Not applicable.}

\section{Ethics approval and consent to participate}

Not applicable.

\section{Funding}

This work was supported by Core Research for Evolutional Science and Technology (CREST) of Promoting Globalization on Strategic Basic Research Programs of the Japan Science and Technology Agency. The study was also partially supported by a National Cheng Kung University project, as part of a second-phase 5-year 50-billion dollar grant from the Taiwanese government to JSC, a Grant-in-Aid for Kurita Water and Environment Foundation to SA (No. 13A021), and JSPS KAKENHI Grant Numbers JP 26117716 and JP16K18836 to $\mathrm{SA}$.

\section{Publisher's Note}

Springer Nature remains neutral with regard to jurisdictional claims in published maps and institutional affiliations.

Received: 7 September 2016 Accepted: 14 February 2018

Published online: 27 February 2018

\section{References}

1. Aikawa S, Ho SH, Nakanishi A, Chang JS, Hasunuma T, Kondo A. Improving polyglucan production in cyanobacteria and microalgae via cultivation design and metabolic engineering. Biotechnol J. 2015;10:886-98.

2. Chew KW, Yap JY, Show PL, Suan NH, Juan JC, Ling TC, et al. Microalgae biorefinery: high value products perspectives. Bioresour Technol. 2017;229:53-62.

3. Aikawa S, Izumi Y, Matsuda F, Hasunuma T, Chang JS, Kondo A. Synergistic enhancement of glycogen production in Arthrospira platensis by optimization of light intensity and nitrate supply. Bioresour Technol. 2012;108:211-5.

4. Aikawa S, Nishida A, Ho SH, Chang JS, Hasunuma T, Kondo A. Glycogen production for biofuels by the euryhaline cyanobacteria Synechococcus 
sp. strain PCC 7002 from an oceanic environment. Biotechnol Biofuels. 2014;7:88

5. Ho SH, Huang SW, Chen CY, Hasunuma T, Kondo A, Chang JS. Bioethanol production using carbohydrate-rich microalgae biomass as feedstock. Bioresour Technol. 2013;135:191-8.

6. Dismukes GC, Carrieri D, Bennette N, Ananyev GM, Posewitz MC. Aquatic phototrophs: efficient alternatives to land-based crops for biofuels. Curr Opin Biotechnol. 2008;19:235-40.

7. Melis A. Solar energy conversion efficiencies in photosynthesis: minimizing the chlorophyll antennae to maximize efficiency. Plant Sci. 2009; 177:272-80.

8. Aikawa S, Joseph A, Yamada R, Izumi Y, Yamagishi T, Matsuda F, et al. Direct conversion of Spirulina to ethanol without pretreatment or enzymatic hydrolysis processes. Energy Environ Sci. 2013;6:1844-9.

9. Ho SH, Chen YD, Chang CY, Lai YY, Chen CY, Kondo A, et al. Feasibility of $\mathrm{CO}_{2}$ mitigation and carbohydrate production by microalga Scenedesmus obliquus CNW-N used for bioethanol fermentation under outdoor conditions: effects of seasonal changes. Biotechnol Biofuels. 2017;10:27.

10. Choi SP, Nguyen MT, Sim SJ. Enzymatic pretreatment of Chlamydomonas reinhardtii biomass for ethanol production. Bioresour Technol. 2010;101:5330-6.

11. Miranda JR, Passarinho PC, Gouveia L. Bioethanol production from Scenedesmus obliquus sugars: the influence of photobioreactors and culture conditions on biomass production. Appl Microbiol Biotechnol. 2012;96:555-64.

12. Möllers KB, Cannella D, Jørgensen H, Frigaard NU. Cyanobacterial biomass as carbohydrate and nutrient feedstock for bioethanol production by yeast fermentation. Biotechnol Biofuels. 2014;7:64.

13. Nguyen MT, Choi SP, Lee J, Lee JH, Sim SJ. Hydrothermal acid pretreatment of Chlamydomonas reinhardtii biomass for ethanol production. J Microbiol Biotechnol. 2009;19:161-6.

14. Zhou N, Zhang Y, Wu X, Gong X, Wang Q. Hydrolysis of Chlorella biomass for fermentable sugars in the presence of $\mathrm{HCl}$ and $\mathrm{MgCl}_{2}$. Bioresour Technol. 2011;102:10158-61.

15. Dong T, Knoshaug EP, Davis R, Laurens LML, Wychen SV, Pienkos PT, Nagle N. Combined algal processing: a novel integrated biorefinery process to produce algal biofuels and bioproducts. Algal Res. 2016;19:316-23.

16. D'haeze W, Holsters M. Surface polysaccharides enable bacteria to evade plant immunity. Trends Microbiol. 2004;12:555-61.

17. Cosloy SD, Oishi M. Genetic engineering in Escherichia coli K12. Proc Natl Acad Sci. 1973;70:84-7.

18. Vaara M, Vaara T, Jensen M, Helander I, Nurminen M, Rietschel ET, Mäkelä $\mathrm{PH}$. Characterization of the lipopolysaccharide from the polymyxin-resistant pmrA mutants of Salmonella typhimurium. FEBS Lett. 1981;129:145-9.

19. Nikaido H. Molecular basis of bacterial outer membrane permeability revisited. Microbiol Rev. 2003;67:593-656.

20. Nakagawa M, Takamura Y, Yagi O. Isolation and characterization of the slime from a cyanobacterium, Microcystis aeruginosa K-3A. Agric Biol Chem. 1987;51:329-37.

21. Snyder S, Kim D, McIntosh TJ. Lipopolysaccharide bilayer structure: effect of chemotype, core mutations, divalent cations, and temperature. Biochem. 1999;38:10758-67.

22. Kučerka N, Papp-Szabo E, Nieh MP, Harroun TA, Schooling SR, Pencer J, et al. Effect of cations on the structure of bilayers formed by lipopolysaccharides isolated from Pseudomonas aeruginosa PAO1. J Phys Chem B. 2008; 112:8057-62.

23. Pink DA, Hansen LT, Gill TA, Quinn BE, Jericho MH, Beveridge TJ. Divalent calcium ions inhibit the penetration of protamine through the polysaccharide brush of the outer membrane of Gram-negative bacteria. Lagmuir. 2003;19:8852-8.

24. Garidel P, Rappolt M, Schromm AB, Howe J, Lohner K, Andrä J, Koch MHJ, et al. Divalent cations affect chain mobility and aggregate structure of lipopolysaccharide from Salmonella minnesota reflected in a decrease of its biological activity. Biochim Biophys Acta. 2005;1715:122-31.

25. Filali MR, Cornet JF, Fontane T, Fournet B, Dubertret G. Production, isolation and preliminary characterization of the exopolysaccharide of the cyanobacterium Spirulina platensis. Biotechnol Lett. 1993;15:567-72.

26. Madson PW, Lococo DB. Recovery of volatile products from dilute highfouling process streams. Appl Biochem Biotechnol. 2000;84-86:1049-61.
27. Wei $P$, Cheng $L H$, Zhang $L$, Xu XH, Chen HL, Gao CJ. A review of membrane technology for bioethanol production. Renew Sust Energy Rev. 2014:30:388-400.

28. Vane LM, Alvarez FR, Rosenblum L, Govindaswamy S. Efficient ethanol recovery from yeast fermentation broth with integrated distillationmembrane process. Ind Eng Chem Res. 2013;52:1033-41.

29. Kadam KL, Newman MM. Development of a low-cost fermentation medium for ethanol production from biomass. Appl Microbiol Biotechnol. 1997;47:625-9.

30. Belay A. Mass culture of Spirulina outdoors-the earthrise farms experience. In: Vonshak A, editor. Spirulina platensis (Arthrospira). London: Taylor and Francis Ltd.; 1997. p. 131-58.

31. Hong KK, Nielsen J. Metabolic engineering of Saccharomyces cerevisiae: a key cell factory platform for future biorefineries. Cell Mol Life Sci. 2012;69:2671-90.

32. Christenson L, Sims R. Production and harvesting of microalgae for wastewater treatment, biofuels, and bioproducts. Biotech Adv. 2011;29:686-702.

33. Pimentel D, Patzek TW. Ethanol production using corn, switchgrass, and wood; biodiesel production using soybean and sunflower. Nat Resour Res. 2005;14:65-75.

34. Brennan L, Owende P. Biofuels from microalgae - a review of technologies for production, processing, and extractions of biofuels and coproducts. Renew Sust Energy Rev. 2010;14:557-77.

35. Markou G, Georgakakis D. Cultivation of filamentous cyanobacteria (bluegreen algae) in agro-industrial wastes and wastewaters: a review. Appl Energy. 2011;88:3389-401.

36. Inokuma K, Yoshida T, Ishii J, Hasunuma T, Kondo A. Efficient co-displaying and artificial ratio control of a-amylase and glucoamylase on the yeast cell surface by using combinations of different anchoring domains. Appl Microbiol Biotechnol. 2015:99:1655-63.

37. Lee MC, Chen YC, Peng TC. Two-stage culture method for optimized polysaccharide production in Spirulina platensis. J Sci Food Agric. 2012;92:1562-9.

38. Matano Y, Hasunuma T, Kondo A. Display of cellulases on the cell surface of Saccharomyces cerevisiae for high yield ethanol production from highsolid lignocellulosic biomass. Bioresour Technol. 2012;108:128-33.

39. Schutyser MAl, Padding JT, Weber FJ, Briels WJ, Rinzema A, Boom R. Discreate particle simulations predicting mixing behavior of solid substrate particles in a rotating drum fermenter. Biotechnol Bioeng. 2001;75:666-75.

40. Woo JM, Yang KM, Kim SU, Blank LM, Park JB. High temperature stimulates acetic acid accumulation and enhances the growth inhibition and ethanol production by Saccharomyces cerevisiae under fermenting conditions. Appl Microbiol Biotechnol. 2014;98:6085-94.

41. Hasunuma T, Kondo A. Consolidated bioprocessing and simultaneous saccharification and fermentation of lignocellulose to ethanol with thermotolerant yeast strains. Process Biolchem. 2012;47:1287-94.

42. Izumi Y, Aikawa S, Matsuda F, Hasunuma T, Kondo A. Aqueous size-exclusion chromatographic method for the quantification of cyanobacterial native glycogen. J Chromaogr B. 2013;930:90-7.

\section{Submit your next manuscript to BioMed Central and we will help you at every step:}

- We accept pre-submission inquiries

- Our selector tool helps you to find the most relevant journal

- We provide round the clock customer support

- Convenient online submission

- Thorough peer review

- Inclusion in PubMed and all major indexing services

- Maximum visibility for your research

Submit your manuscript at www.biomedcentral.com/submit 